ISTVÁN M. BUGÁR

\title{
HIPPOLYTUS RECAST AND A LATE ANTIQUE DIES IRAE*
}

\begin{abstract}
Summary: The paper aims at casting some light on the intellectual and social context of an eschatological treatise transmitted under the name of Hippolytus (De consummatione mundi, CPG 1910) and a closely related metrical homily in Greek attributed to Ephrem of Syria and preserved in different versions (CPG 3946, 4012). The first of the two texts has long been known to be a reworking of a genuine work of Hippolytus on the subject (De Christo et Antichristo, CPG 1872) and its close relation to the Ephrem Graecus text has also been observed. In my paper I propose new clues as to the dating of these texts and explore in which way the eschatological vision of Hippolytus has been updated in the pseudepigraphon.
\end{abstract}

Keywords: Hippolytus, Pseudo-Hippolytus, Ephraem Graecus, Romanus Melodus, eschatology

The following paper aims at casting some light on the intellectual and social context of an eschatological treatise transmitted under the name of Hippolytus and a closely related metrical homily in Greek attributed to Ephrem of Syria. The first of these has long been known to be a reworking of a genuine work of Hippolytus on the subject, and its close relation to the Ephraem Graecus text has also been observed. This, however, helps little in dating either of them, except for setting the banal terminus post quem for the former. Indeed, a wide range of settings - from the fourth to the ninth centuries - have been proposed in the otherwise scanty research spent on these works; settings that quite significantly differ. To start with, in his ground-braking (and ageold) monograph, W. Bousset was ready to accept that the Ephremian homily is indeed by the Syrian Church Father, or at least contemporaneous with him, ${ }^{1}$ while

* The present paper was read at the Survival of Early Christian Traditions: 10th Annual Conference of the Asia- Pacific Early Christian Studies Society, 9-11 September, 2016, St Petersburg, Russia.

${ }^{1}$ Bousset, W.: The Antichrist Legend: A Chapter in Christian and Jewish Folklore. Tr. by A. H. KEANE. London: Hutchinson and Co. 1896, 35. The early dating is accepted without further argument by E. GRYPEOU: Ephraem Graecus, 'Sermo In Adventum Domini': A Contribution to the Study of the Transmission of Apocalyptic Motifs in Greek, Latin and Syriac Traditions in Late Antiquity”. In S. KH. SAMIR - J. P. 
pseudo-Hippolytus - as it follows from Bousset's argument - may even be earlier. ${ }^{2}$ At the other extreme, $\mathrm{H}$. Achelis some two years later accepted a dating into the ninth century or later for pseudo-Hippolytus. ${ }^{3}$ The most recent (and nearly unique) study I am aware of devoted to this text proposed the time of the Arab conquest. ${ }^{4}$ In the following I am going to look for clues that help to settle the question.

Hippolytus was particularly sensitive to eschatological problems. Although the commentary on Revelations supposed by Achelis and Jerome proved to have never existed, ${ }^{5}$ he at least defended the authority of the book against challenges by Gaius of Rome $;{ }^{6}$ and although the description of hell in the fragmentary De universo is most certainly wrongly attributed to him, ${ }^{7}$ he appears to have composed at least one treatise on resurrection. ${ }^{8}$ But the most influential was his only treatise preserved intact, De Christo et Antichristo $\left(C P G 1872 ; \mathrm{BHG}^{\mathrm{n}} 812 \mathrm{zb}\right.$, henceforth $\left.\left.C A\right)\right)^{9}$ Its one-time popu-

MONFERRER-SALA (eds.): Graeco-Latina et Orientalia: Studia in honorem Angeli Urbani heptagenarii. Cordoba 2013, 165-82.

${ }^{2}$ Cf. Bousset (n. 1) 33-42; esp. 41.

${ }^{3}$ ACHELIS, H.: Hippolytstudien [Texte und Untersuchungen zur Geschichte der altchristlichen Literatur [henceforth TU] 16/4]. Leipzig 1897, 79. I have not been able to trace the Russian study he is referring to.

${ }^{4}$ WHEALEY, A.: De consummatione mundi of Pseudo-Hippolytus: another Byzantine apocalypse from the early Islamic period. Byzantion 66 (1996) 461-469.

${ }^{5}$ ACHELIS (n. 3) 71; for the supposed fragments, see Griechische Christliche Schriftsteller [henceforth GCS] 1/II, 229-238; for further literature, see GEERARD, M. (ed.): Clavis Patrum Graecorum. 3 vols. Turnhout: Brepols, 1974-1983 [henceforth CPG], no. 1890.

${ }^{6}$ See $C P G$ (n. 5) 1891 (and 1331); the fragments preserved in Syriac by Dionysius-bar-Salibi have never been fully collected; for a useful initiative see Roger Pearse's collection on http://www.tertullian.org/ fathers/dionysius_syrus_revelation_01.htm [accessed 27 October 2015] (for some of the fragments in Achelis' German translation, see $G C S$ [n. 5] 1/II, 251-253). The following new fragments should be added: BROCK, S. P.: Catalogue of Syriac Fragments (New Finds) in the Library of the Monastery of Saint Catherine, Mount Sinai. Athens, Mount Sinai Foundation 1995, 17-19, 93-94, 94-96, 196-197 (description, text, translation, facsimile), repeated in CAMPLANI, A. - PRINZIVALLI, E.: Sul significato dei nuovi frammenti siriaci dei Capitula adversus Caium attribuiti a Ippolito. Augustinianum 38 (1998) 49-82.

${ }^{7}$ See HILL, C. E.: Hades of Hippolytus or Tartarus of Tertullian? The Authorship of the Fragment De Universo. Vigiliae Christianae 43 (1989) 105-126. What he in fact proves is that the argument in the work is incompatible with works safely attributed to Hippolytus, while no such inconsistency appears with other works of "Iōsēpos" - the author preserved in the textual tradition, most probably identical with the Roman heresiologist, Pseudo-Origen, the author of Refutation omnium haeresium. For the best available hypothesis solving the riddle of the relationship of the two sets of work sometimes both attributed to Hippolytus, see BRENT, A.: Hippolytus and the Roman Church in the Third Century: Communities in Tension before the Emergence of a Monarch-bishop. Leiden: Brill 1995; and BRENT, A.: Was Hippolytus a Schismatic? Vigiliae Christianae 49 (1995) 215-44.

${ }^{8} C P G 1900$ De resurrectione ad Mammaeam imperatricem; possibly identical with $C P G 1901$ De resurrectione et incorruptibilitate, and with the Armenian fragment "against the Valentinians". I also take it that the designation refers to the content and not the title; cf. RICHARD, M.: Les difficultés d'une édition des oeuvres de S. Hippolyte. Studia Patristica 12 (1975) 51-70, 69. The suggestion by A. Whealey to attribute the pseudo-Justinian De resurrectione to Hippolytus (or, in fact, either to Hippolytus or the Roman heresiologist) does not appear plausible; its attitude towards, and unbiased use of philosophy makes it distinct not only from these two authors, but virtually from any other possible candidate: WHEALEY, A.: Hippolytus' Lost "De Universo" and "De resurrectione": Some New Hypotheses. Vigiliae Christianae 50 (1996) 244-256; and again: WHEALEY, A.: Pseudo-Justin's De resurrectione: Athenagoras or Hippolytus? Vigiliae Christianae 60 (2006) 420-430.

${ }^{9}$ Recently J. A. CERRATO suggested that the text is meant as a manual for catechetical instruction: Hippolytus and Cyril of Jerusalem on the Antichrist: When Did an Antichrist Theology First Emerge in 
larity is witnessed by the Syriac, Armenian, Ethiopian, Georgian and Old Slavonic translations,${ }^{10}$ the quotations in the Sacra parallela, and further references in Jerome, Anastasius of Sinai, Germanus of Constantinople, the Vita Andreae Sali, Dionysiusbar-Salibi, in catenas and in commentaries on the Revelations. ${ }^{11}$ Hippolytus deals with the matter once again extensively in his Commentary on Daniel, ${ }^{12}$ where he elaborates some issues while at the same time referring the reader to his earlier $C A .{ }^{13}$

Photius, who reviews $C A$ in conjunction with Hippolytus' Commentary on Daniel, highlights the interrelation of the two works and their archaic eschatology while appreciating their pioneering accomplishment. He points to the chronological speculations that have proved false in the meantime, since Hippolytus located the Incarnation in the middle of the sixth millennium, and the final times at the end of it, that is to say, around $500 \mathrm{CE} .{ }^{14}$ While this theory is explicit in the Commentary alone, ${ }^{15}$ it may have contributed to the decline of the authority of Hippolytus' eschatological views and could have provided the need for their reconsideration.

The De consummatione mundi (CPG 1910; henceforth $C M$ ) has accomplished this adjustment, by selecting form the original, reformulating the details, and adding a considerable eschatological material from other sources. With its 90 or so surviving manuscripts - as opposed to the six of $C A^{16}$ - it has soon appropriated the popularity of the ancient Hippolytus, thus becoming the most popular work on the subject. Traces of an Armenian translation have also been preserved. ${ }^{17}$ Despite of the rich manuscript tradition the text lacks a critical edition, since with antiquarian interest of modernity it has lost its value after having proven a pseudepigraphon. Achelis simply reproduces the 1557 Paris edition of Joannes Picus. ${ }^{18}$

Early Christian Baptismal Catechesis? In DALY, R. J. (ed.): Apocalyptic Thought in Early Christianity. Grand Rapids, MI: Baker Academic 2009, 154-159.

${ }^{10}$ Texts, editions, or witnesses enumerated in $C P G 1872$

${ }^{11}$ OvERBECK, FR. C.: Quaestionum Hippolytearum specimen. Jena: Schreiber \& fil. 1864, 12-42, and ACHELIS (n. 3) 71-92.

${ }^{12}$ Hippolytus, in Danielem [henceforth inDn] II 11-13; IV 5-10; 12-14; and esp. 16-24 and 48-60. A first English translation of the commentary dated to 2010 by T. C SCHMIDT, based on the critical text of M. Richard, is in circulation. It would very well deserve to be (re)published after due revision.

${ }_{13}$ inDn IV 7. 1; 13. 1.

${ }^{14}$ Photius, Bibliotheca cod. 202: 164a

${ }^{15}$ inDn IV 23-24: GCS 1/1, 246-248; followed by Commodianus, Carmen de duobus populis//carmen apologeticum 791: Corpus Scriptorum Ecclesiasticorum Latinorum [henceforth CSEL] 15, 172 (ed. B. DOMBART; in English see http://christianlatin.blogspot.com/2008/08/excerpt-from-commodianuscarmen.html [accessed 10 January 2014] tr. by D. M. KLEIN); Institutiones II 38. 8: CSEL 15, 111; and Lactantius, DI VII 14. 9. The commentary inDn, however, also warns against calculations (IV 16-22, esp. 16. 2; 18; 19.1-7) before introducing the date which, in its turn, is repeated in In Davidem et Goliath 7. 9; 7. 13 (in German tr. by N. BONWETSCH, TU 26/1, 84. 9-27; 85. 16-18).

${ }^{16}$ As attested by the database PINAKES: http://pinakes.irht.cnrs.fr [accessed 30 November 2013]. One of the 90, coming from the library of the Hungarian renaissance notable, Joannes Sambucus, is found at the University Library in Budapest: ELTE gr. 3 xvi. sz. fol. 079-92: cf. MONOK, I. (ed.): A Zsámbokykönyvtár katalógusa (1578) Gulyás Pál olvasatában [The catalogue of the library of Joannes Sambucus in the reading of Pál Gulyás]. Szeged: Scriptum 1992, no. 2595 (I am indebted to Péter Tóth, British Museum for tracing the origin of the ms.). Further five manuscripts preserve extracts from $C M$.

${ }^{17}$ PITRA, J-B.: Analecta Sacra Spicilegio Solesmensi parata. 4 vol. Paris 1876-1884, II 236-239.

${ }^{18}$ GCS 1/II, 289-309. 
Although Hippolytus' name has been kept in the tituli of the manuscripts, ${ }^{19}$ there is no sign in the text that it has been intended as a forgery. ${ }^{20}$ Its dating is a hard task due to the lack of direct evidence. The suggestion that it were connected to the Arab conquest $^{21}$ appears unfounded. In fact there is no trace of the events surrounding the Arab expansion in our text, unlike in the apocalyptic texts from the mid-seventh century, where the allusions cannot be overlooked. ${ }^{22}$ Actually, as I shall argue, all signs in our text point in the direction that in $C M$ we are before the cataclysm of the midseventh century and the watershed of Pseudo-Methodius in apocalyptic literature. In fact $C M$ envisages a stable Christian empire even to the eschaton, while in Pseudo-Methodius we encounter with the decline and fall of the Roman Empire, which is then restored, with its new sovereign offering the crown to Christ in Jerusalem ${ }^{23}$ just before the time of the Antichrist. I would also be inclined to place $C M$ before the emerging series of Revelation-commentaries from the end of the sixth century on the basis of their different eschatological traditions unknown to our author. "Before", however, should not be understood in a strictly chronological sense, since the latter works do not appear to have been widely perused. ${ }^{25}$

The radical political changes of the fourth century can serve as a terminus post quem, since the treatise obviously reflects the new order with its ecclesiastical and social

${ }^{19}$ The title itself ПEPI TH $\Sigma \Sigma$ YNTE $\Lambda$ EIA $\Sigma$ TOY KO KMOY * KAI ПEPI TOY ANTIXPI $\Sigma$ TOY *

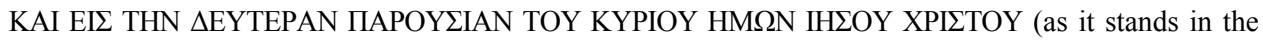
edited text) is telling. It includes partly the title of Hippolytus' work (ПEPI TOY ANTIXPI 2 TOY), partly

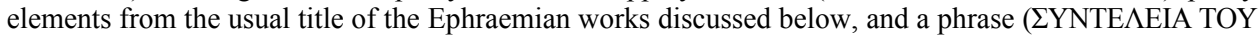
KO $\Sigma \mathrm{MOY}$ ) so characteristic of Hippolytus ( $C A 46 ; 64 ; \mathrm{InDn}$ IV $5.3 ; 6.3 ; 22.1$ ). The New Testament form

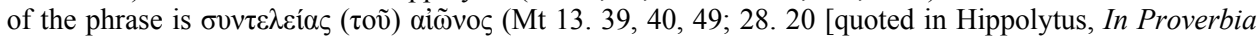
fr. 74 ed. Richard], and Heb 9. 26).

${ }^{20}$ As is rightly remarked by WHEALEY: De consummatione (n. 4) 462.

${ }^{21}$ WHEALEY: De consummatione (n. 4) 461-469.

${ }^{22}$ For Pseudo-Methodius, see AlEXANDER, P. J.: The Byzantine Apocalyptic Tradition. Ed. by D. DE F. ABRAHAMSE. Berkeley - Los Angeles - London: University of California Press 1985, 20; cf. also PseudoEphrem, Sermones III/5: CSCO 320-1 1 (Syr 138-139): 5: 138. 60-71 (German translation: 139. 79-94).

${ }^{23}$ ALEXANDER (n. 22) 22. This motive, as I am convinced, is inspired by the events in the Himyarite Kingdom, where Christians are finally saved by the Ethiopian king, who offers his crown to Christ in Jerusalem. For the historical episode and the literary sources, see CHRISTIDES, V.: The Himyarite-Ethiopian war and the Ethiopian occupation of South Arabia in the acts of Gregentius (ca. 530 AD). Annales d'Ethiopie 9 (1972) 115-146.

${ }^{24}$ On Oecumenius and Andrew of Caesarea, see ODEN, TH. C.: Introduction. In Greek Commentaries on Revelation: Oecumenius, Andrew of Caesarea. Trans. by W. C. WeINRICH. Downers Grove, IL: InterVarsity Press 2011, xix-xxxii; and xxxii-xxxix; on Andrew, see further CONSTANTINOU, E. S.: Andrew of Caesarea and the Apocalypse in the Ancient Church of the East: Studies and Translation. PhD Diss. Faculté de Theologie et des Sciences Religieuses de l'Université Laval, Québec 2008 [I am grateful to György Geréby for drawing my attention to this work]; the first half of the dissertation in book form: CONSTANTINOU, E. S.: Guiding to a Blessed End: Andrew of Caesarea and His Apocalypse Commentary in the Ancient Church. Washington, DC: Catholic University of America Press 2013, esp. 4771 (The second part of the thesis, the translation of the text and the notes, have also come out as a book: Andrew of Caesarea, Commentary on the Apocalypse. Trans. by E. S. CONSTANTINOU [Fathers of the Church 123]. Catholic University of America Press 2011. For the difference of the traditions, see below.

${ }^{25}$ On the aftermath of Andrew, see CONSTANTINOU: "Guiding to a Blessed End" (n. 24) 298-304. Its real discovery begins in the second millennium. 
consequences. Further, the author seems to use - or is at least closely related to - a material in Ephraem Graecus - a material that is of course equally difficult to date, but is most probably post-Ephremian. Although there is also a larger set of apocalyptic texts in Ephraem Graecus, ${ }^{26}$ in fact it is a single metrical homily that is concerned with the apocalyptic times before the parousia and offers parallels with $C M$. This, a sort of Dies irae of its own time, has been preserved in two versions: Sermo in adventum domini, et de consummatione saeculi, et in adventum antichristi (CPG 3946; henceforth $C S A)^{27}$ - transmitted in 68 manuscripts; ${ }^{28}$ and In aduentum domini (sermo i-iii) $(C P G 4012 \mathrm{abc} \text {; henceforth } A D)^{29}$ preserved in 3 codices. ${ }^{30}$ In the following I shall concentrate on the mutual relationship of these two texts and of $C M$, trying to establish their parentage.

The first version (CSA) was one of the two (or three) most popular eschatological sermons of Ephraem Graecus, based on the number of manuscripts. It largely coincides with $A D$ I-III, but adds a prooimion on the inaptness of the author - naming himself Ephrem ${ }^{31}$ - to describe the final cataclysm. This short introduction ends with a summary of the terrible future events. ${ }^{32}$ There follow $A D$ I-III with omissions (in a few places the absent bit is summarized in a prose sentence) ${ }^{33}$ In $A D$ I the form is octosyllabic (couplets), in $A D$ II the metrum becomes heptasyllabic couplets, from $A D$ III

${ }^{26}$ BOUSSET (n. 1) 38-41. Bousset points out that it is a single treatise on the Second Coming that is reproduced as a part of five different composite sermons (CPG 3944, 3945, 3948, 4013, 4019), but in fact it relates only the end of the apocalypsis.

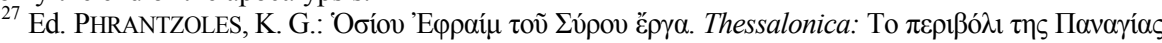
IV (1992) 111-128; ASSEMANI, G. S. (ed.): Sancti patris nostri Ephraem Syri Opera omnia quae exstant Graece, Syriace, Latine. Vol II: Graece et Latine. Roma 1743, 222b-230c (references henceforth are to Phrantzoles' page numbers).

${ }^{28}$ As attested by the database PINAKES: http://pinakes.irht.cnrs.fr [accessed 30 November 2013]. CPG 3946 enumerates also Syriac, Christian Palestinian Aramaic, Latin, Arabic, Armenian and Slavic translations/versions; out of which the Syriac (given also under 4012) is nothing else than the Syriac sermon mentioned in $\mathrm{n}$. 22. It has nothing to do with our sermons.

${ }^{29}$ PHRANTZOLES (n. 27) IV (1992) 180-184; 185-191; 192-199. = ASSEMANI (n. 27) III 134-143.

${ }^{30}$ As attested by the database PINAKES: http://pinakes.irht.cnrs.fr [accessed 30 November 2013]: (1) Oxford, Bodleian Roe 28, 61v-68v*, saec. xi (contains also the other version and two further eschatological sermons of Ephraem Graecus, as well as other Patristic texts connected to the veneration of icons); (2) Paris, Bibliothèque nationale de France gr. 1188, 88-90v*, saec. xi (a collection of Ephraem Graecus and Chrysostomus, In 1Cor; (3) ibid., gr. 0987, 222-234*, saec. xvi (various Patristic theological texts and homilies). The classification of the different versions in the manuscripts is, however, not reliable in the databese; some textual witnesses to the $C A$ version are enumerated also under $C P G 4012$. $C P G 4012$ also enumerates Syriac, Latin and Slavonic versions; out of which the Syriac is identical with the text under $C P G 3946$ (see n. 28 above), and has nothing to do with our texts. Bousset adduces also a Latin discourse under the name of Ephraem/Isidore of Seville (CPL 1144), which he dates to the fourth century and considers to be even closer to $C M$, but neither of these claims appear to be justified. The discourse is preoccupied with the Persians and the decay of Rome, which the author expects to occur in the immediate future inaugurating the apocalyptic times. Caspari's dating (some time before 628) fits both this context and the attribution to Isidore (cf. CPL 1144). Nonetheless, for a few details, it will be quoted below.

${ }^{31}$ This does not amount to a forgery, since Ephrem is a common monastic name, and may well be the name of the compilator.

${ }^{32}$ Pp. 112-116 ed. Phrantzoles.

${ }^{33}$ E.g. $A D$ pp. 189-190; CSA 121. 
it is again octosyllabic. ${ }^{34}$ As a rule, the edited text of $A D$ gives a much better reading and preserves more consistently the metrum - albeit not without overturning it sometimes by words added or deleted. Occasionally, however, the apparently right text can be restored from CSA. Nevertheless, without a critical edition these observations have a restricted value. Furhter, in spite of its primordial form, $A D$ also has a prose addition at the end of sermo II and an otherwise metric passage on the fornication of Israel with Midiam breaks the train of thought at the beginning, after the first 33 lines. There are also telling surpluses in $A D$, which I shall discuss in detail further down, since here it seems impossible to tell whether the short or the long version is the more original.

This short overview suffices to prove that although as a general rule $A D$ preserves an older version of the text, the two versions do not depend on each other, but on a more ancient form of the text, which has not been transmitted (henceforth $\mathrm{Ur}-A D)^{35}$ Since CSA has been translated into Christian Palestinian Aramaic, and the translation is unlikely to have taken place later than the eighth century, ${ }^{36} \mathrm{Ur}-A D$ is likely to be considerably earlier. This impression is confirmed by the absence of specific themes, which makes it "pre-Methodian", that is to say, pre-Islamic.

Now let us look briefly at the other peculiarities of the $A D$ version. (1) After the first 12 lines of sermo $\mathrm{II}^{37}$ it adds a metrical hymn and a supplication. (2) Further down - again preserving the metrum - there is a Christological excursus not quite appropriately fit into the train of thought. ${ }^{38}$ (3) More significant for our present purpose is the "anti-Semite" line added, ${ }^{39}$ followed by the prediction of the alliance of Jews, Edomites, Moab, and Ammon under the Antichrist, which latter motive is absent from the $C M$, but appears in Hippolytus' $C A 51 .^{40}$ (4) There is a prose addition drawing the morals and summarizing the final disasters at the end of sermo II, which repeats nearly verbatim the last three metric lines attested both by $A D$ and $C S A{ }^{41}$ It includes the motive of the damage of fishes known from the $C M,{ }^{42}$ but this appears also in the metric parts of sermo III. (5) Two metric lines are explained in prose; ${ }^{43}(6)$ and, more significantly there is a surplus of 6 lines in $A D$ emphasizing God's mercy and His will of universal salvation. ${ }^{44}$ This might be understood as a sign of "Origenist" ten-

${ }^{34}$ BOUSSET ([n. 1] 37) differentiates two forms; stanzas of 7 lines of 14 syllables each with a caesura in the middle, and stanzas of 4 lines of 16 syllables each with a caesura in the middle, although I cannot clearly see the stanzas in the text as we have it. D. HEMMERDINGER-ILIADOU (Éphrem grec. In Dictionnaire de Spiritualité. Vol. 4, Paris: Beauchesne 1960, 805) lists $A D$ (and CSA) among the metric pieces ("tetrasyllaba or heptasyllaba").

${ }^{35}$ There appears also a common defect of the two versions; they end with an identical prosaic sentence, where the language suggests a poetic form but the metrum is hopelessly obscured.

${ }^{36}$ Cf. Morgenstern, M.: Christian Palestinian Aramaic. In The Semitic Languages. Ed. by ST. WENINGER. Berlin: de Gruyter 2011, 628-637, esp. 629-630.

${ }^{37}$ P. 185.

${ }^{38}$ Pp. $186-187$.

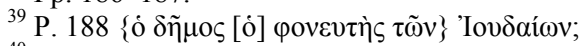

${ }^{40} \mathrm{Cf}$. also inDn IV 53. 2

${ }^{41}$ Pp. $190-191$.

${ }^{42}$ It is, however, inspired by Rev. 8,8-9.

${ }^{43}$ P. 189.

${ }^{44}$ P. 196. 
dencies of the version, or, vice versa, an anti-Origenist deletion from version CSA; but the assertion is general enough, ${ }^{45}$ so that this is not necessarily the case. Certainly, should the (actual) version be assigned to the 530s, the otherwise innocent lines might have served as a shibboleth for the different parties.

A linguistic analysis of $C M$, while confirming the obvious terminus post quem, does not carry us far either in establishing the date. Further, the value of such an investigation is highly diminished by the large number of the manuscripts and a lack of anything like a critical edition. Thus I shall highlight only a few characteristic syntagmas. The epithet "theologian" of the apostle John, which occurs twice in the treatise, is first found in the fourth century in the East. ${ }^{46}$ The expression theeggoroi apostoloi $(C M 10)$ is extremely rare, but the adjective used for different apostles is widespread from the fifth century. ${ }^{47}$ The term hierarchēs ${ }^{48}$ is introduced by Pseudo-Dionysius. ${ }^{49}$ Finally, while I have found no instances of the syntagma panachrantou kai theotokou Marias (CM 1) in this form, theotokos is conventional from the fourth-fifth century, and panachrantos is spreading from the sixth century. ${ }^{50}$ At any rate, such a liturgical formula ${ }^{51}$ gets easily introduced in a text through the process of reproduction, as we can see it, for example, in the case of the Armenian fragment of Aristides, ${ }^{52}$ or, more tellingly, in the only surviving Greek text of Hippolytus' In Benedic-

${ }^{45}$ Cf. e.g. $C A 3$ quoted below.

${ }^{46} C M 10$ and 21. The Thesaurus Linguae Graecae [henceforth $T L G$ ] database attests the following occurrences before the eighth century: Doctrina patrum; Chronicon paschale (7th c.); Oecumenius, In Apoc.; Malalas (6th c.); Pseudo-Dionysius, Ep. 10 (title); Theodoretus, In Isaiam; De trinitate; Romanus Melodus (this will be significant for us later); Cyril of Alexandria, De Trinitate; Pseudo-Didymus, De Trinitate (5th c.); Cyril of Jerusalem, Catecheses 12.1 (an author probably used directly or indirectly by $C M$ ); Gregory of Nyssa, De sancto Theodoro PG 46, 748; Asterius of Emesa, Or. 8. 12 (4th c.). It is also attested in some texts not safely datable: some spuria of Chrysostom; and more significantly in the anonymous Scholia in Apocalypsem. On this work see below. Harnack advancing the impossible attribution to Origen tries to provide early parallels for the epithet, but in fact fails to do so: DIOBOUNITIS, C. - HARNACK, A. VON: Der Scholien-Kommentar des Origenes zur Apokalypse Johannis [TU 38/3]. Leipzig: Hinrichs 1911, 48. By his "Ephrem" (without locus) we must probably understand Ephraem Graecus, where we have several instances, among others in some eschatological texts (CPG 3944, 3945, 4016); and for the dating of Acta Timothei (CANT 295) Lipsius has convincing evidence (between 325 and 356/375): LIPSIUS, R. A.: Die apokryphen Apostelgeschichten und Apostellegenden. Bd. II 2. Braunschweig 1884, 385. For searching, I have also made use of P. J. Heslin's excellent software, Diogenes 3,1.6 (http://www.durham.ac.uk/p.j.heslin/ Software/Diogenes/).

${ }^{47}$ Heliodorus (Aethiopica II 4. 3), Nonnus (Dionysiaca 10 times; Paraphrasis sancti evangelii Joannei 15 times), Cyril of Alexandria (19 times), Acts of the council of Ephesus (16 times, once referring to the apostles).

${ }^{48} C M 41$, in the final addition.

${ }^{49} 67$ occurrences in De ecclesiastica hierarchia, 12 in De caelesti hierarchia, and further 5 elsewhere in the corpus without earlier occurrences.

${ }_{50}^{50}$ Paulus Silentiarius, Descriptio Sanctae Sophiae 720; Romanus Melodus, Cantica 15. 9.

${ }^{51} 14$ occurrences in the prayers of the Ephraem Graecus corpus. At any rate mss. BNF 1217 xii 35v and BNF 771 xiv 19r do not bring the full formula as printed in the edition of $C M$. To be sure, in the case of such pious formulas with a liturgical background, expansion is more probable than contraction during the reproduction of the text.

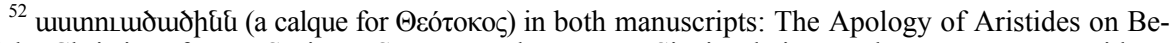
half of the Christians from a Syriac MS. Preserved on Mount Sinai. Ed., intr., tr. by J. R. HARRIS. With an Appendix Containing the Main Portion of the Original Greek Text by J. A. RoBINSON. Cambridge: Uni- 
tionem Isaac et Jacob. ${ }^{53}$ Nonetheless, the cumulative effect of these observations is that the fifth or sixth century is more probable as the earliest possible date for our text.

Our general impression thus far gains considerable support from the fact that the closest parallels for the schemes of the eschatology of $C M$ and its idiom can be found beside $A D$-CSA in Romanus Melodus' Hymn 50 - an evidence unnoticed by Bousset, or Whealey. ${ }^{54}$ While several concurrences will be noted later, let me accentuate only the extraordinary motive of the flight of the Antichrist and the idioms used to describe it. ${ }^{55}$ This link reinforces that our text fits into a well definable context, which spans chronologically from the end of the fifth to the first half of the sixth century, from Zeno's Henoticon to the Second Council of Constantinople - the period when Romanus was active. As a geographical space, I consider Asia Minor and Syria the most likely, as suggested by the epithet of the apostle John; ${ }^{56}$ the use of the devices of the poetical-homiletical language of Melito of Sardis; ${ }^{57}$ and finally by the theopaschite language, which may suggest a pre-Chalcedonian, or more probably anti-Chalcedonian, or neoChalcedonian background. ${ }^{58}$

In the following I shall analyse the theological, social and eschatological views of the author of $C M$ by disclosing the differences from its model, the $C A$ of Hippolytus. ${ }^{59}$ The reworking is partly of technical nature and is not relevant for the history of doctrine and ideas. Thus while Hippolytus addresses a certain Theophilus, ${ }^{60}$ the redactor transforms the discourse into a homily intended for the Christ-loving ( $p h i-$ lochristoi) people in general, ${ }^{61}$ and by consequence omits the dedication, introduction and invocation. Sometimes he embellishes, ${ }^{62}$ sometimes he abbreviates the

versity Press $1893^{2}, 29,32$; for the Armenian of the Venice ms., see PITRA (n. 17) IV (Paris 1883) 8. This gave rise to an interesting episode in the history of textual scholarship; E. Renan, after the publication of the Armenian fragment but before the discovery of the Syriac translation (and the Greek reworking) argued from this addition that the text is late: J. R. HARRIS, The Apology of Aristides 2-3.

${ }^{53}$ Hippolytus, In Benedictionem Isaac et Jacob 1: apparatus ad PO 27. 6.6 (cf. TU 38. 13. 5-8): again a passage on the Theotokos.

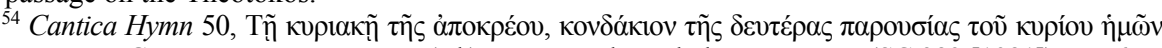

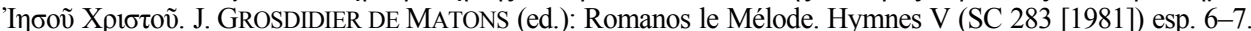
Th. M Wehofer, however, has observed the connection between Romanos's hymn and Ephraem Graecus: TH. M. WeHOFER: Untersuchungen zum Lied des Romanos auf die Wiederkunft des Herrn. Sitzungberichte der Kais. Akademie der Wissenschaften in Wien, Philosophisch-historische Klasse 154/5. Wien 1907, 20-28.

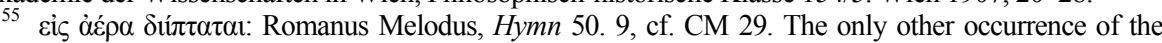

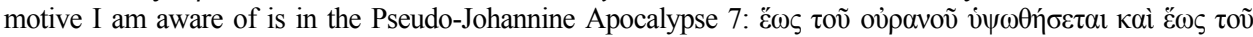

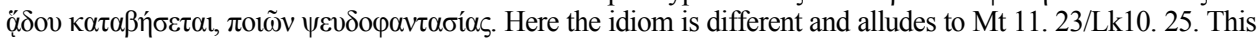
text is probably rightly dated by Whealey to the eighth century (at least if we suppose that it has come into being as a single unit, which is not at all certain): see WHEALEY, A.: The Apocryphal Apocalypse of John: A Byzantine Apocalypse from the Early Islamic Period. Journal of Theological Studies 53 (2002) 533-540.

${ }^{56}$ Most of the occurrences before the eighth century listed above (n. 46) can be located to this territory and the very first instances can be linked to Ephesus.

${ }_{58}^{57}$ Esp. CM 43, 45.

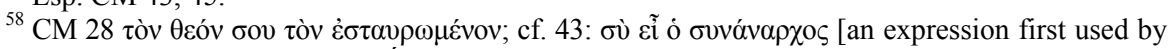

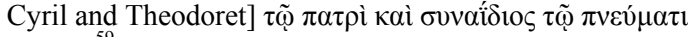

${ }^{59}$ This natural methodology is followed also by Whealey, although with different results.

${ }^{60} C A 1,2,67$.

${ }^{61} C M 1$.

${ }^{62}$ Pl. $C M 2$, cf. $C A 2$. 
text, ${ }^{63}$ and changes the structure. These latter moves are occasionally indicated by phrases like "Where shall I begin?", or "Let us return", ${ }^{64}$ while on other instances the traces of the displacement are carelessly left behind ${ }^{65}$ It is quite sensible that the author transfers the prophecy of Daniel to the commencement, since it begins with what is a past for the Christian writer, and then he turns to the narrative of the Antichrist, while the structure of Hippolytus' discourse is far less lucid. The latter emphatically does not go beyond providing a collection of testimonies, ${ }^{66}$ whereas in the redaction explanation is expanded at the expense of quotations. There the book of Revelation is cited far less frequently and the unidentifiable apocryphon quoted twice by Hippolytus is omitted. ${ }^{67}$ Besides these changes, three sections are inserted to the text: first, the collection of eschatological testimonies is amended (CM 3-11), but from the well-defined point of view of the redactor, focusing on natural catastrophes, moral decline and the spread of heretical doctrine, subjects barely touched upon by Hippolytus. Secondly, $C M$ provides a strictly chronological overview of the activity of the Antichrist (CM 22-27 and 29-34), mainly - but not exclusively - from elements present also in Hippolytus' treatise. Finally, he concludes with a homily on the last judgement on the basis of Mt 24. The redactor of $C M$ aiming at completeness, seems to have used - directly or indirectly - Hippolitean material other than the $C A$, too. ${ }^{68}$ Interestingly enough, this is also true of the Ehpraemian homily. The eschatological descriptions of inDn contain several poetical details ${ }^{69}$ echoed in Ephraem Graecus. ${ }^{70}$

${ }^{63}$ E.g. c. 1; the interpretation of Daniel's prophesies, etc.

${ }^{64} C M 1,2,11$.

${ }^{65} C M$ 20ex; cf. $C A 6$

${ }^{66} C A 1,67$

${ }^{67}$ CA 15, 54. Cf. DENIS, A.-M.: Fragmenta pseudepigraphorum quae supersunt Graeca. Leiden: Brill 1970, 231 (Fragmenta Anonyma d); the quotation is not known from elsewhere.

${ }^{68}$ For a salient motif, the cessation of Christian Eucharist, see p. 220 below.

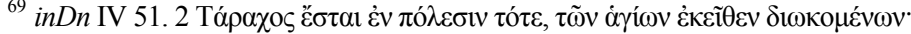

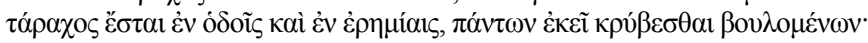

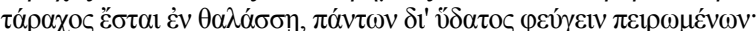

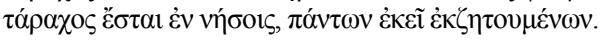

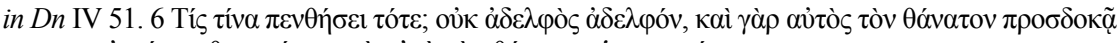

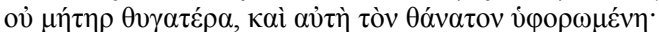

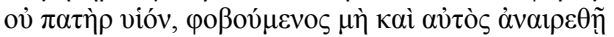

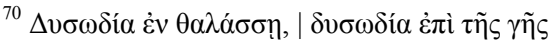

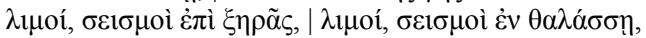

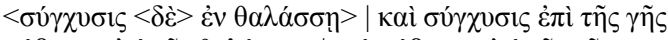

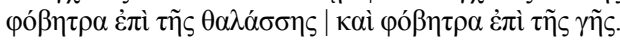
(both $A D$ III [p. 193 Phrantzoles] and CSA)

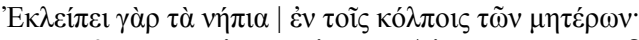

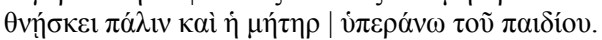

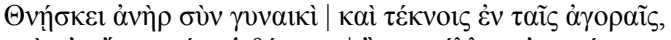

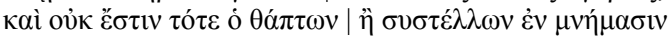

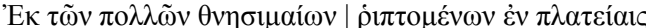
$\delta v \sigma \omega \delta i ́ \alpha \pi \alpha v \tau \alpha \chi o ́ \theta \varepsilon v . .$. (both $A D$ III [p. 192 Phrantzoles] and CSA)

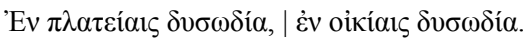

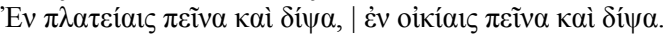


What is salient at the first comparison of $C A$ and $C M$ is, however, the difference of perspectives. Thus, their dissimilar relation to the Roman Empire is obvious in their exegesis of the vision of Daniel as it appears from the changes made by the redactor ( $C A$ 25; $C M$ 16). What was an external and accidental political actuality for Hippolytus becomes the glorious leading power in the entire oecumene. While Hippolytus details the crash of Rome following Revelations ( $C A$ 31-42), the entire subject is left out from the redaction, as well as the earlier reference to it in the explanation of Daniel's vision (CA 26-28). While the redactor preserves most of the quotations here, he does not even mention either the collapse of the Empire or the saints' taking over the power. He also preserves the transition from the previous subject ( $C A 29, C M 17)$, but instead of turning to Rome's fate he announces the ultimate anomy and error. In writings after the Arab conquest, however, the humiliation and rebirth of the Empire plays a crucial role. ${ }^{71}$

In line with this, where Hippolytus asserts that in the time of the Antichrist the veneration of the imperial image will be obligatory ( $C A 49)$, the compiler of $C M$ (c. 28 ) replaces this by the enforcement of apostasy, since saluting the image of the Emperor remained a constituent of the political protocol in the Christianized Empire so much so that the Antichrist-aspirant Julian, by depicting pagan deities on imperial images, exploited them for persuading Christians to venerate them. ${ }^{72}$

Although the redactor emphasises the necessity of social solidarity and the mutual nature of obligations, he sees the world in an essentially hierarchical perspective. He reveals this when enumerating both the saved and the damned in his description of the last judgement at the end of his homily. We see hierarchs having administered the sacrifice of the holy body and blood every day of their life, as well as ascetics heading to heaven, but the same orders are represented among the condemned together with grudging tax collectors, cruel soldiers, emperors, governors and bishops (CM 38). ${ }^{73}$ Thus the author preserves the idea of égalité before God expressed so powerfully by Hippolytus:

For He casts away none of His servants as unworthy of the divine mysteries. He does not esteem the rich man more highly than the poor, nor does He despise the poor man for his poverty. He does not disdain the barbarian, nor does He set the eunuch aside as no man. He does not hate

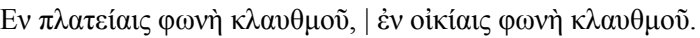

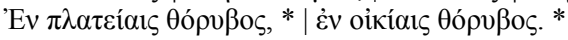

Eĩ

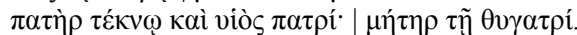

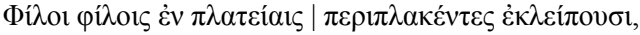

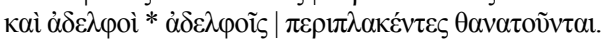
( $A D$ III [p. 194 ed. Phrantzoles] partly completed from CSA)

${ }^{71}$ Ps-Methodius, see AleXander (n. 22) 20, 22; Ps-Ephrem, Sermones III/5: CSCO 320-1 (Syr 138-139): 5 : 138. 60-71 (German translation: 139. 79-94) lines 300 sqq.

${ }_{72}$ See esp. Gregory Nazianzen, Contra Iulianum I 80: $P G 35,605 \mathrm{C}$ ence of $C M$.

${ }^{73}$ This motif is reproduced in the pseudo-Johannine Apocalypse c. 24, in my view under the influ- 
the female on account of the woman's act of disobedience in the beginning, nor does He reject the male on account of the man's transgression. But He seeks all, and desires to save all, wishing to make all the children of God, and calling all the saints unto one perfect man. ${ }^{74}$

For Hippolytus the social hierarchy opposed to this equality is still not even sub specie saeculi huius eternally fixed datum, for in the eschaton democracies replace the kingdoms before the Antichrist appears.

Thus the redactor concentrates on other aspects of the apocalypsis than Hippolytus. For the latter the persecution of Christians is the central event, whereas the former focuses on moral decay and on natural (one would even say ecological) catastrophes. For the latter persecution was the most immediate experience as plastically described in the Commentary on Daniel. ${ }^{75}$ By contrast, the compiler speaks about the martyrs in past tense (CM 30), comparing them to those that will suffer under the Antichrist. $^{76}$ The perspective is the same as that of Cyril of Jerusalem writing some one or two hundred years earlier. ${ }^{77}$ For his audience, the liminal situation is no more an everyday experience and thus the eschatological awareness is no more psychologically motivated. On the contrary, they need to be repeatedly warned $(C M 1) \cdot{ }^{78}$ For them immediate experience highlighted something else:

all people turn against one another, there is envy, hatred, argument, pastors disregard their flock, lay people are disobediently disposed towards priests, everybody follows his or her own will, parental and marital bounds lose their power, elderly people and children are no more revered, social solidarity ceases, corruption increases, churches are used for profane purposes, the Scriptures are ignored but occult practices are ever more popular, pseudo-apostles attract followers from sham Christians (tōn dokountōn einai christianōn). Priests turn into wolfs, monks become secular. (CM 6-7)

The vision of the internal corruption of the Church in an eschatological perspective is already present in Cyril of Jerusalem, ${ }^{79}$ but also in the inserted passage of the Ascensio Isaiae. ${ }^{80}$ While the common dating of this text situates it at the end of the first century $\mathrm{CE},{ }^{81} \mathrm{I}$ doubt that this would be the context of the passage concerned. Lac-

${ }^{74}$ CA 3, translation by S. D. F. SALMOND. In Fathers of the Third Century: Hippolytus, Cyprian, Caius, Novatian, Appendix. Ed. by A. ROBERTS - J. DONALDSON [Library of Ante-Nicene Fathers 5]. Edinburgh: T\&T Clark 1886, 205 (Digital version: http://www.ccel.org/ccel/schaff/anf05.html; henceforth ANF 5).

${ }^{75}$ Hippolytus, inDn I 14-16, 20-21, II 14-28, 35-38, III 16, 22.

${ }^{76} \mathrm{Cf}$. $C A 25$ and $C M 16$.

${ }^{77}$ Cyril of Jerusalem, Catecheses 15. 17.

${ }^{78}$ The Commentary on Revelations by Andrew of Caesarea shares this perspective in spite of not being inclined to a moralizing allegorical interpretation of eschatological prophecies as opposed to Oecumenius.

${ }^{79}$ Cyril of Jerusalem, Catecheses 15. 7.

${ }^{80}$ Ascensio Isaiae 3. 21-30. Ed. E. H. CHARLES. London 1900, 92-96.

${ }^{81}$ KNIBB, M. A.: Martyrdom and Ascension of Isaiah. In The Old Testament Pseudepigrapha. Ed. by J. H. CHARLESWORTH. Garden City, NY: Doubleday \& Co. 1985, II 143-155, esp. 149. Knibb tries to adduce early parallels for the "internal critique": 1-2Tim; $2 \mathrm{Pt}$; $1 \mathrm{Clem} 3$. 
tantius at least, at the end of persecutions sees the eschatological moral corruption essentially in the social and political and definitely not in the ecclesiastical sphere, though he speaks to a different audience. ${ }^{82}$ For the author of $C M$ the process proceeds parallel in the two spheres. As a result, in the last judgement we do not only see baptised and confirmed Christians perfected in doctrine among the condemned, but also ascetics.

It is quite in tune with this that $C M$ interprets the prophecy of Isaiah on the abandonment of the daughter of Sion differently from Hippolytus. While $C A 30$ understands it as referring to Israel, $C M 3$ takes it as alluding to the Church. ${ }^{83}$ This involves not only the prophanization of Churches mentioned before, but in the climax of the apocalyptic times also the complete cessation of Eucharistic liturgy (CM 34). This latter motif occurs both in the metric homily of Ephraem Graecus ${ }^{84}$ and in Romanus Melodus. ${ }^{85}$ Commodianus attests this as an early tradition, ${ }^{86}$ and in fact its first occurrence is in Hippolytus. ${ }^{87}$

As in Ephraem Graecus the cessation of the mass induces a cosmic mourning, in the $C M$ the social and ecclesiastical crisis is accompanied by natural catastrophes, which he details more than once $(C M 8,27)$. Let me quote from the second passage of $C M$ :

the heavens will not give their dew, the clouds will not give their rain, the earth will refuse to yield its fruits, the sea shall be filled with stench, the rivers shall be dried up, the fish of the sea shall die, men shall perish of hunger and thirst $[\ldots]^{88}$

The description is ultimately inspired by Revelations 8 and $16,{ }^{89}$ but the images and the idiom are quite different. Further, the subject is not prominent in Hippolytus. ${ }^{90}$

${ }^{82}$ Lactantius, DI VII 15. 8-9, 17. 9.

${ }^{83}$ Early Patristic commentaries on Isaiah do not count with this possible meaning. What is meant by the prophecy is the demolition of the Temple for Eusebius In Isaiam I 12-13, the fate of Israel for Chrysostom, In Isaiam I 3-4; Theodoretus, Interpretatio eclogario in Isaiam prophetam PG 81, 222-226; Cyril of Alexandria, Commentarius in Isaiam PG 70, 24-28. The latter - less emphatically though - also envisages a mystical interpretation about the soul. A similar double deciphering with the accent on the second can be found in the Enarratio in Isaiam attributed to Basil 19-21 PG 30, 147-157, similarly in Procopius, Commentarii in Isaiam PG 87, 1836-1840. The same texts (both), however, come closer to the $C M$ when Is 1,6 is at least interpreted to refer to the Church, namely schisms: in $P G 30,147$ (c. 18); $P G$ 87, 1836-1840.

${ }^{84}$ 198. 3-5; 126. 10 - 127. 2 ed. Phrantzoles. The text can be tentatively restored in the following way using the printed versions:

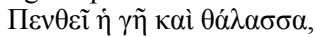

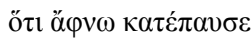

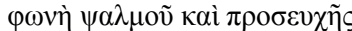

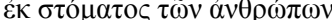

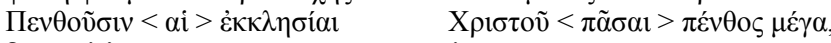

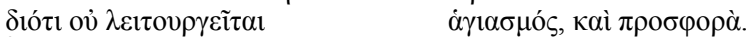

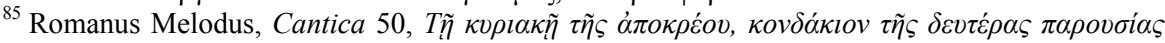

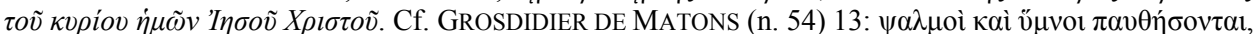

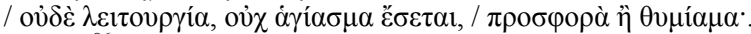

${ }^{86}$ Carmen apologeticum 879 in CSEL 15, 172 (ed. Dombart): tunc erit nec oblatio Christo.

${ }^{87}$ inDn IV 35. 3; cf. less clearly expounded in Adversus Gaium fr. a verso col. 2. p. 93 ed. Brock (translation: pp. 94-95).

${ }^{88}$ Translation from $A N F 5$, p. 249.

${ }^{89}$ Cf. e.g. Lactantius DI VII 16. 6-7.

${ }^{90}$ Nevertheless, the imagery of Revelations appears also in Hippolytus' inDn IV 51. 3. 
The model and the copy also differ in their exegesis. The cryptic number-sign of the Antichrist features in both, but the deciphering is quite different. Hippolytus provides three possible explanations with caution, repeated in a longer list by the later commentators on Revelations, with or without naming him as a source. ${ }^{91}$ Our author does not accept any of the twelve solutions proposed by these authors, but comes up with his own (APNOYME), ${ }^{92}$ which, in its turn, is not repeated by any of the commentators. In a sense, this is the most original contribution of the author, since it does not appear in either $A D / C S A$ or Romanus. Neither of them is in fact preoccupied with secret codes.

Whealey takes this suggestion as a proof of the setting of the Arab invasions, but it can be understood so only by way of petitio principii. I assume it is developed from one of the two key eschatological passages of the New Testament (apart from Revelations): 2Thess, where apostasy $(\dot{\alpha} \pi 0 \sigma \tau \alpha \sigma i \alpha)^{93}$ is featured. The noun was soon understood as actually the name of the Antichrist. ${ }^{94}$

The compiler of $C M$ omits the description and interpretation of the vision of the woman clothed with the Sun, so prominent in Hippolytus (CA 60-61), who interprets it as referring to the Church. ${ }^{95} \mathrm{He}$ also leaves out the curious explanation of the parable of the unjust judge and the persistent widow (Lk 18) peculiar to Hippolytus, who takes the judge to refer to the Antichrist (CA 56-57). The redactor does not seem to favour allegory, so he omits the allegorical explanation of the image of the ship in Isaiah (CA 58-59).

The detailing of the career of the Antichrist, however, exhibits in both versions ${ }^{96}$ a contrast to a passage of the Roman heresiologist, author of the Refutatio omnium haeresium, a text once attributed to Hippolytus. ${ }^{97}$ The latter apparently unaware of the tradition concerning the Antichrist says in his summary of Judaism that they expect another Messiah, from the house of David, born of man and woman, who shall collect (episynaxei $)^{98}$ Israel, restore the Temple-cult, defeat the nations, but die in a battle, and then comes the end (synteleia) ${ }^{99}$ of the world and its conflagration

${ }^{91}$ Hoskier, H. C. (ed.): The Complete Commentary of Oecumenius on the Apocalypse. Ann Arbor: University of Michigan Press 1928, 157-158; Andreas of Caesarea (c. 38: PG 106, 340); Arethas (c. 38; $P G$ 106,681); Dionysius CSCO Syr 18. p. 17-18 [lat], CSCO Syr 18. 23. By contrast, Irenaeus emphasizes the impossibility of decipherment: $A H$ V 30. 1-3; quoted by Eusebius, $H E$ V 8. 5-6; and by the Sacra parallela in HoLl, K.: Fragmente vornicänischer Kirchenväter aus den Sacra Parallela. Leipzig 1899, frr. 171-172.

92 "I deny" - with a careless orthography; $\alpha$ was widely pronounced as $\varepsilon$ possibly as early as the 2nd century BC, but at least in the Early Byzantine period: HORROCKS, G.: Greek: A History of the Language and its Speakers. Chichester: Wiley-Blackwell 2010², 167-168.

${ }^{93} 2$ Thes 2. 3 .

${ }^{94}$ Gregory Nazianzen, Carmina moralia $\Lambda \Delta^{\prime}$ Definitiones minus exactae ("O $37,963.8-9$.

${ }_{95}$ Cf. also Adversus Gaium fr. a verso col. 1. p. 93. ed. Brock (translation on p. 94). Andrew of Caesarea is familiar both with this interpretations and the one found in Oecumenius - who interprets the image to the Theotokos - but favours the former in line with his insistence on the historical (eschatological) meaning: c. 33: $P G$ 106, 320-321.

${ }_{97}^{96}$ CA 6 and 64; CM 19-20, 22.

${ }^{97}$ Refutatio omnium haeresium IX 30. 6-8. On the delicate issue of the authorship, see n. 7. above.

${ }^{98} \mathrm{Cf} . \dot{\varepsilon} \pi \iota \sigma v \alpha \dot{\xi} \xi \varepsilon 1$ in $C A$; $\sigma 0 v \alpha \dot{\xi} \xi \varepsilon 1$ in the printed edition of $C M 20$.

${ }^{99}$ Cf. CA 5, 19, 46, 64; CM 2, 3, 9, 11, 12, 36, 42. 
(ekpyrósis). ${ }^{100}$ It appears that Hippolytus, in his turn, exploits this tradition while describing the Antichrist. The redactor, then, builds a full-fledged Antichristology on a remark by Hippolytus that the Antichrist imitates Christ. ${ }^{101}$ This latter principle is present also in Origen, ${ }^{102}$ and then evolves through Cyril of Jerusalem ${ }^{103}$ to Theodoret of Cyrrhus. ${ }^{104}$ In the $C M$ it extends to his birth without a father, thus he is going to be an incarnation of the Devil ${ }^{105}$ - albeit a virtual one, since the Devil is not able to create a body. Basing himself on the Antichristology, the compiler often replaces Hippolytus' "Antichrist" simply by Diabolos. ${ }^{106}$ This rhymes with his theopaschite-oriented Christology, which we have observed.

To sum it up, the redactor is not familiar either with the exegetical tradition of Revelations evolving from the late sixth century or with the perspective of pseudoMethodius. He is closely related both to the metrical homily preserved in two forms under the name of Ephrem and to Romanus Melodus. The most important precursor in his version of the eschatological scenario is Cyril of Jerusalem. His orientation will stand out clearer if we compare it to the commentary of the Apocalypsis discovered by Diobounitis. Although von Harnack's extravagant attribution to Origen ${ }^{107}$ is impossible, the text is certainly pre-Oecumenian, sharing with Origen and Oecumenius a number of exegetical priorities. Although only the first half survives, it is obvious that historical eschatology is out of interest for the author, who concentrates on spiritual exegesis and noetic meaning. At the same time, the epithet of John shared by this work and $C M^{108}$ together with the possible time-range might be taken as an indicator that the two texts do not stand afar from each other in space and time. However, unlike in the fragmentary commentary, the expectation of the historical parousia in the $C M$ is alive, even if the faithful in his environment have to be constantly reminded. Times since Hippolytus have definitely changed. For him, quite to the contrary, it was the disciplina arcani concerning the issue that had to be kept in mind $(C A 1) .{ }^{109}$

\author{
István M. Bugár \\ Department of Philosophy \\ University of Debrecen
}

${ }^{100}$ Cf. $C A 5,64$.

${ }^{101}$ CM 22-27, cf. CA 6. The development, however, is not alien to Hippolytus; In Davidem et Goliath 10,4 (in German $T U$ 26/1, 87. 6-23) we find a history of the manifestations of the Antichrist in the Old Testament parallel to that of the Logos (compare esp. Melito of Sardis fr. 15 for the formula, and Hippolytus, In Benedictionem Isaac et Jacob 2. 14, 22. 9-10 for the idea).

${ }_{102}$ Catena in Matthaeum (Paris. Coislin. gr. 23). CrAMER, J. A. (ed.): Catenae Graecorum patrum in Novum Testamentum I. Oxford: Oxford University Press 1840, 105.

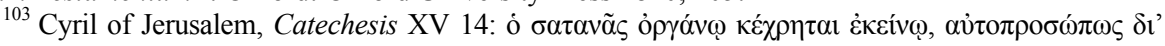

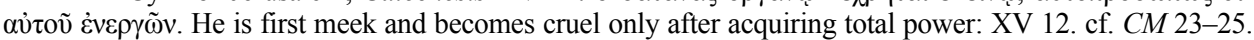
In Lactantius we have an Antichrist malo spiritu genitus (Lactantius, DI VII 17. 2).

${ }^{104}$ Theodoret, Haereticorum fabularum compendium V 22: $P G$ 83, 532. 1-16.

${ }^{105}$ In Hippolytus he is at least the son of the Devil: $C A$ 56-57.

${ }^{106}$ Compare CA 6-CM 19b; CA $14-C M 19 \mathrm{a} ; C A 47-C M 21$.

${ }^{107}$ DIOBOUNITIS-HARNACK (n. 46) 45-48.

${ }^{108}$ See n. 46 above.

109 On this, see CERRATO (n. 9) 156-158. 